\title{
The 50-year jubileum of the Society for the Promotion of Eriugenian Studies in the John Scottus Eriugena (815-877) research, 1970-2020
}

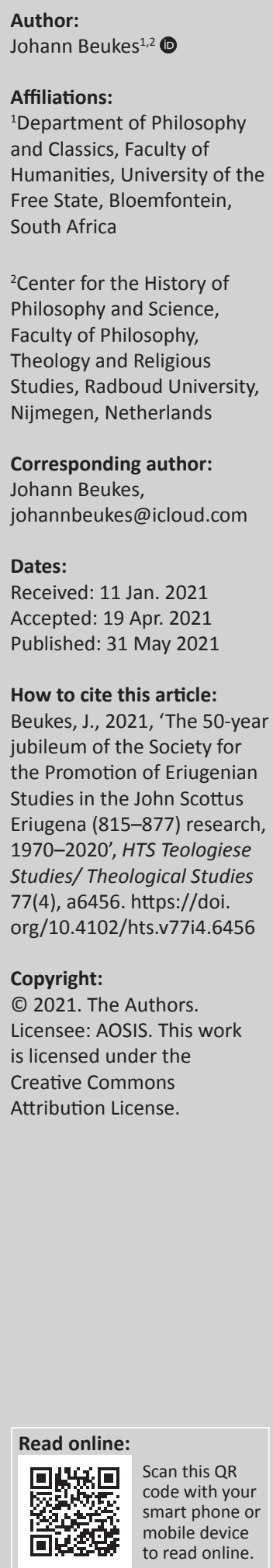

This article charters the history and work of the Society for the Promotion of Eriugenian Studies (SPES), which celebrated its 50-year jubileum in 2020. After a brief introduction to the thought of John Scottus Eriugena (815-877), with emphasis on his primary text (in five volumes), Periphyseon, written between 864 and 866 and condemned as heretical in 1050, 1059,1210 and finally in 1225, the development of SPES over the past five decades is surveyed in detail and connected to an outstanding work published in the Brill's Companions to the Christian Tradition series in Leiden (2020), under the editorship of Adrian Guiu (A Companion to John Scottus Eriugena). The article is descriptive and analytical in its presentation of the relevant history of ideas and synthetical in its attempt to coherently integrate the most recent secondary texts on the relevant philosophical themes in Eriugena research.

Contribution: The article contributes to the Society for the Promotion of Eriugenian Studies' 50-year jubileum by summarising its conference outputs over the past five decades in an extensive overview as well as connecting its work to A Companion to John Scottus Eriugena (Brill, Leiden, 2020), thereby furthering the society's efforts and specialist research outputs to a broader, non-specialised readership.

Keywords: John Scottus Eriugena (815-877); a companion to John Scottus Eriugena; Adrian Guiu; Edouard Jeauneau; Willemien Otten; John O'Meara; Periphyseon; Society for the Promotion of Eriugena Studies; SPES; Inglis Sheldon-Williams.

\section{Introduction}

More than three centuries after it was written, the primary text of the only speculative Western philosopher from the Carolingian period in Medieval philosophy met a cruel fate. John Scottus Eriugena's (815-877) magistral five-volume dialogue Periphyseon (written between 864 and 866; cf. Eriugena 1996-2003), in which an enigmatic speculative philosophy was developed based on both the Greek and Latin patristic and philosophical traditions and which could be regarded as a sophisticated philosophical interchange between the Medieval West and East, was condemned as heretical in 1050, 1059, 1210 and finally in 1225, as a precursor to the infamous Paris condemnations of 1277. The final condemnation of the Periphyseon compromised its commentary potential and steady historical reception as well as restricted the stature and influence of its author in high scholasticism. Given the 'widespread antipathy towards philosophical thought' (Lahey 2020:448) in early 13th-century Paris, several theologians interpreted the Periphyseon as pantheistic and declared its contents heretical, thereby rendering the work effectively obsolete. All available copies of the work were sent to Rome by Pope Honorius III (Cencio Savelli, 1150-1227, Pope 1216-1227) to be destroyed. A few manuscripts nevertheless stayed in circulation and the work was eventually printed in Oxford in 1681, but this printed version was put on the infamous Index of Prohibited Books in 1684 and kept on it for nearly three centuries, before the Index itself expired in the 1960s (cf. Carabine 2000:23).

The consequence of the Periphyseon's unfortunate condemnation is that the specialist Eriugena research ${ }^{1}$ is still a relatively young domain, given the vastness and age of the standardised Medieval canon. It was only in 1925 and 1933 that solid introductions to Eriugena's life and thought were presented in an exquisite English monography by Henry Bett from Cambridge University (Johannes Scotus Erigena: A Study in Medieval Philosophy; Bett 1925) and a magnificent French (Louvain) dissertation by Maïeul Cappuyns (Jean Scot Érigène. Sa vie, son oeuvre, sa pensée;

1.For accessible introductions to Eriugena's life and work, see Bett (1925:11-33); Carabine (2000:13-26); Copleston (1993:112-135); Costambeys, Innes and MacLean (2014:1-30); Grabmann (1957:192-214); Haren (1985:75-82); Hyman, Walsh and Williams (2010:145-148); Marenbon (1981:88-111, 1988:48-52); McKitterick (2004:1-27); Moran (1989:35-47, 1990:131-151, 2008); Otten (1991:40-81); Sheldon-Williams (1967:518-531) and Weiner (2007:1-40). 
Cappuyns 1933), both to a large extent based on cross references between Eriugena and several early scholastics preceding 1225 , thus before its final condemnation.

\section{John Scottus Eriugena (815-877) and the Periphyseon (864-866)}

Eriugena seems to be 'a man of many names' (Carabine 2000:13): in Irish Gaelic and English alone he is referred to as John Scottus Eriugena, Iohannes Scotus, Scottigena and Erigena, with several variations in English and other languages. There probably will never be consensus about an authentic or 'correct' proper name. In addition, there is often confusion outside the discipline of Medieval philosophy regarding the 'other John Scotus' (John Duns Scotus, Duns Scotus or simply 'Scotus', ca. 1266-1308), the remarkable Franciscan from the late 13th century. However, the confusion surrounding Eriugena's many names is unnecessary: both Scot $(t)$ us and Eri(u)gena, or the more forced Scottigena, simply indicate that this court scholar ${ }^{2}$ 'Iohannes' hailed from Ireland and gave himself the tautological sobriquet 'Scottus Eriugena' ('John Irish, the Irish-born'; cf. Siewers 2020:9) - because he wanted to emphasise his Irish heritage and Northern English connection with Alcuin (730-804), the formidable academic administrator and monastery reformer from York and later principal of the Carolingian palace school in Aix-la-Chapelle. To avoid confusion with the 13th-century John Duns Scotus, the custom in contemporary research is that John Scottus Eriugena is referred to simply as 'Eriugena', with the exception of titles and abstracts of books and articles on Eriugena, where the full (presumed) name is normally used.

Eriugena arrived in the 840s at the Carolingian court of Charlemagne's ('Charles the Great', 748-814) grandson, Charles II ('The Bald', 823-877). He lectured the seven liberal arts (the trivium and quadrivium) for some time at the palace school, extensively employing Boethius' (ca.477-524) De Consolatione Philosophiae, also in preparation for the writing of his magnum opus, the Periphyseon. From Eriugena's preliminary notes it is clear that he considered the liberal arts as the key prerequisite to Biblical exegesis (cf. Kavanagh 2020:326). In fact, Eriugena emphasised the (although hyperbolic) early Medieval exegetical principle: nemo intrat in caelum nisi per philosophiam ['no one enters heaven other than by philosophy']. The liberal arts is the ancilla ('handmaid') of the study of the canonised texts. Without philosophy, no proper theology is possible.

As a court scholar, Eriugena had no responsibilities or obligations in the church as such. However, in his capacity as lecturer at the palace school he got involved in a robust church debate concerning divine predestination, in which his erudition in Greek, Latin and patrology impressed the emperor. Given the Carolingian court's positive attitude toward the Hellenistic heritage, Charles II requested that

\footnotetext{
2.It has often been assumed that Eriugena was a monk, but little is known about his life before he appeared at the Carolingian court in the 840 s. He likely studied in Irish monastic schools and had 'no distinguished rank within the church' [...] which 'could mean that he was a simple monk, although no other document of the time makes mean that he was a simple monk, although no other document of the time makes
reference to this fact' (Carabine 2000:14; with acknowledegment of two anonymous reference to this fact' (Carabine 2000:14; with acknow
reviewers' questions and comments in this regard).
}

Eriugena translated the complete, extant Pseudo-Dionysius corpus from Greek into Latin. Another translation of the Dionysian corpus was, however, already completed in 827 by the abbot Hilduin of Saint Denis, chaplain to Charles' father, Louis I ('The Pious', 778-840), by request of the emperor of Constantinople, Michael II (770-829). This translation was presented as a gift to Louis, yet Charles demanded a unique translation from the Carolingian court. Eriugena swiftly completed the new translation with distinction, on grounds of which he became the emperor's academic guest and protégé. ${ }^{3}$

Eriugena, thus, initially made impact on the Carolingian court as an arts lecturer, followed by his role as a court translator specialising in translations from Greek to Latin (cf. Carabine 2000:16-17; Erismann 2020:93): Apart from his translation of the Corpus Dionysiacum, he also embarked on translating the Quaestiones ad Thalassium of Maximus Confessor and the De hominis opificio of Gregory of Nyssa (which Eriugena retitled as De imagine). These translations distinguished Eriugena from his contemporaries, precisely because very few Western scholars were able to read Greek (just as few Greek writers from Byzantium could read Latin). It was indeed the quality of his translation of the Corpus Dionysiacum that left the impression that Eriugena was the only thinker who could somehow 'unite' Rome and Athens in Aix-la-Chapelle: the quality reveals itself therein that Eriugena was not intimidated by technical problems in translating the always obscure Dionysius' Neoplatonic conceptualisations but illuminated them with creative expositions $^{4}$ in Latin. With this translation Eriugena penetrated the heart of Neoplatonism which he systematically redeveloped in a unique and original speculative philosophy,

3.The translated Corpus Dionysiacum consists of De Divinis Nominibus (The Divine Names), De Mystica Theologia (The Mystical Theology), De Coelesti Hierarchia (The Celestial Hierarchy), De Ecclesiastica Hierarchia (The Ecclesiastical Hierarchy) and Epistulae (Letters). These editorial titles of the Dionysian corpus are not straightforward: Eriugena (in Periphyseon IV 757C and 759C; Corpus Christianorum Continuatio Mediaevalis 164238.1139 \& 246.1274-5), for instance, refers to De Mystica Theologia as Symbolica Theologia (on Eriugena's translation of De Mystica Mystica Theologia as Symbolica Theologia (on Eriugena's translation of De Mystica
Theologia as such, see Harrington 2004:22-30). The source of the above translated Theologia as such, see Harrington 2004:22-30). The source of the above translated
titles of the Corpus Dionysiacum is those of Rorem (1993:241-243), based on the titles of the Corpus Dionysiacum is those of Rorem (1993:241-243), based on the
critical edition of Suchla, Heil and Ritter (Corpus Dionysiacum, Volumes I \& II, Patristische Texte und Studien, Volumes 33 \& 36, Walter de Gruyter, Berlin \& New Patristische Texte und Studien, Volumes 33 \& 36, Walter de Gruyter, Berlin \& New
York; see Pseudo-Dionysius 1990-1991). For the English translation Rorem used (with an introduction to the translation by himself), see Luibheid (transl.) 1987. The Dionysian writings themselves continued to 'influence the West in the form of Latin translations by Hilduin and Eriugena in the ninth century and by John Sarracenus ( $\mathrm{fl}$ ca.1167) and Robert Grosseteste (ca.1175-1253) in the High Middle Ages, and through commentaries by Eriugena, Hugh of Saint-Victor (d.1142), Thomas Gallus Albert the Great (ca.1200-1280) and Thomas Aquinas (1225-1274)' (Rorem 1993:16). These later translators and commentators of the Dionysian writings in high probability did not know they could often be reading 'Eriugena' on the side (Albert, for one, was certain that 'the whole commentary was [...] the work of Maximus'; Tugwell 1988:40): certain that 'the whole commentary was [...] the work of Maximus'; Tugwell 1988:40) excerpts of the Periphyseon were added to the Corpus Dionysiacum in the Paris Manuscript (ms. Paris, Bibliothèque Nationale, lat. 17341). The anonymous compiler of this manuscript added around 100 passages from the Periphyseon to the papa bibliothecarius Anastasius' (810-878) Latin translation of the Greek scholia (cf. Harrington 2004:2-3, 26-27). This compilation was used as a textbook for students a the University of Paris and 'many other universities and monastery schools' (Harrington 2004:3) and had the effect that Eriugena's 'teachings did not completely disappear, especially in terms of his negative theology and hyperphatic predication of God (super or plus quam) - of course, these were anonymous, so readers of the Paris manuscript did not know they were reading "Eriugena"' (acknowledging an anonymous reviewer's comment with reference to the last sentence).

4.Regarding Eriugena's creative use of language in translations: referring to it as 'neologisms' (as in Beukes 2020:1:128) is probably not nuanced enough, whilst employing terms like 'exposition' and 'creativity' are more subtle and possibly more suitable: 'Rather than summarize or avoid cases in which a direct translation from Greek to Latin is impossible, John chose to include terminological exposition and Greek to Latin is impossible, John chose to include terminological exposition and
nuanced paraphrase in his translations' (Guiu 2020c:5); in the same vein Carabine $(2000: 24)$ states that ' $[d]$ ialectic [...] is Eriugena's method of explication precisely because it is the method of the creative process at work' (author's italics). Also, see Harrington (2004.23-24) on Eriugena's translation of the Greek term 'beyond' (epegeina) as 'summit' (summitas), as an example of Eriugena's rendering of 'the non-cognitive Greek term in cognitive Latin terms' (Harrington 2004:24). 
as presented in the Periphyseon. Eriugena particularly reappraised Dionysius in terms of his consideration of the unknowable nature of God, the role and function of negative theology and the reditus or ascension of all things back to God, but in a broader sense he also re-engaged Eastern fathers such as Maximus Confessor and several diverse receptions of Aristotle, as available in the 9th century.

In terms of his formation as a true Carolingian 'polymath' (Carabine 2000: Preface) and distinctively speculative philosopher, Eriugena's sources were, thus, both the Western and Eastern thinkers. This is what makes Eriugena such an attractive theorist for his own time and, in fact, for any time: he is not to be categorised from one perspective only as 'West' or 'East', or strictly in Western terms, Platonic-Augustinian or steady Aristotelian. His reception of Aristotle is grounded in Porphyry's Isagoge, Boethius' translations of and commentaries on the Aristotelian text in Latin (the aim of which was precisely a reconciliation of Plato and Aristotle), whilst his translation of Maximus Confessor's Quaestiones ad Thalassium contributed to the development of his unique Aristotelianism. His Platonic orientation was profoundly influenced by Neoplatonism, whether via Augustine or the Eastern trajectory of PseudoDionysius. Eriugena was by 864 well prepared to synthesise these influences in an original and exhaustive summa.

The Periphyseon is presented in the form of a dialogue between a nutritor or teacher and an alumnus or student (cf. Lloyd-Sidle 2020:113): this stylistic consideration brings a human element into a dense and difficult text. The alumnus is often confused, shocked, surprised, bored and restless and poses questions from this unsteady disposition which the nutritor then answers with progressive refinement, until the alumnus is satisfied or at least less confused (cf. Lloyd-Sidle 2020:113-115). The work consists of five books or volumes, although Eriugena initially scheduled only four, which he wanted to correspond with his four divisions of nature: the division of being and non-being, the division of the uncreated and the creator, the division of causality and diversity and the division of the human body and soul. The first division provides the depth structure of the work, whilst the second to fourth divisions are divisions of being.

Volume I describes the five modes of being and non-being, presents the four divisions of nature and investigates the first division, which is the role of God as uncreated creator. This investigation into the nature of God is supplemented with an extensive excursus on negative theology, theophany (cf. Barstad 2020:267-268) and the applicability of the 10 Aristotelian categories on divine nature. Volume II defines the second division of nature by examining the primordial causes for diversity in the sensical world. Volume III engages the third division of nature in terms of creation, as a relation between created things' participation in 'something' and 'nothing'. Volume IV essentially presents Eriugena's anthropology and investigates the fourth division in nature in the presumed human dualistic self. Volume V comprises Eriugena's idiosyncratic Neoplatonist eschatology and extends the Neoplatonic notion of reditus, the eventual return of all created things to the creator. Although Eriugena's unique Aristotelian Neoplatonism is clearly present in the Periphyseon, the notion of 'creation' is thematically the basis of each of the five sections, indicating the process in terms of which the unmanifested God becomes visible and how this 'visibility' returns to the unmanifested Selfness of God.

Volume I starts with Eriugena's hyper-inclusive concept of natura or 'nature' (Otten 1991:7-10, 2020a: 189-191): the first and fundamental division of all things, whether it can be grasped by the mind or not, is a division between things that are and things that are not (cf. Haren 1985:75-82). Natura or 'nature' is for Eriugena a general name for all things, for both that which is and that which is not. In other words, every object of thought is already embedded in nature (cf. Eriugena in SheldonWilliams 1968:197). He then isolates five modes of interpretation in this first division, which is the 'basic difference that divides all things' (Eriugena in Sheldon-Williams 1968:198). In the first place, being and non-being are considered in terms of sensibility or perceptibility, which for Eriugena means that beingness can be predicated by either the mind or the senses. God is not perceived in this way and must in terms of this mode of interpretation be predicated as non-being. Secondly, being and non-being is considered in terms of its place in the Neoplatonic hierarchy, which links the creator emanationally descending with the lowest creatures and the lowest creatures ascending and returning toward the creator. In this mode, intellectual ability is crucial: when being is predicated from a creature of a higher order, that creature is absolved of a lower order and vice versa. This is what makes difference between things possible. The third mode of interpretation deals with actualisation in its treatment of the Aristotelian distinction between potentiality and actuality, whilst the fourth considers the faculty of perception, which, in fact, is a refinement of the first mode: when something appears to the mind as true and to the senses as non-true, the Platonic principle that the mind's perception must be prioritized, applies. The fifth and last mode of interpretation deals with the human subject as such and encapsulates Eriugena's notion of free will: this is the mode that understands the subject as the realisation of the image of God, with the logical consequence that when the subject is removed or alienated from a similarity with God, the subject is not.

Volume II deals fourfold with the division of uncreated and creator: firstly, that which is creating but is not created, which is God, the source of creation; secondly, that which is created and is itself creating - clearly pointing to a synthesis of Neoplatonic and Christian notions, in the sense that the Neoplatonic Logos (the expression of the divine mind and the eternal corporality of archetypes in creation), is related to the second Person of the Trinity; thirdly, that which is created and is itself not creating, the subject of Volume III, namely, the cosmos; and lastly, that which is not created and is itself not creating, the subject of volumes IV and V, which is the God of the eternal return of things in the Neoplatonic inversion of the hierarchy, of the body to the soul, of the soul to the causes and of the causes to God, which is everything in all things (cf. Haren 1985:75-82). In the Neoplatonic creative descent downwards and the ascending return of all things to their source, Eriugena 
makes an important distinction between datum ['gift'] and donum ['grace']: datum is the 'initial constitution of all things in being', whilst donum 'represents the virtues by which nature is adorned' (Carabine 2000:57). While being could be considered as the datum of God by which every nature exists in the world, being becomes well-being through the donum of God, allowing every nature not only to participate in the world but also to return to God in eternity (cf. Carabine 2000:57).

Eriugena, thus, maintains the role and adequacy of divine grace but presents it as a grace that enables the 'elected' of God to move even beyond the primordial created state of perfection before the fall of humankind in original sin. This special status that Eriugena ascribes to the 'faithful' is referred to as 'deification', by which Eriugena means the return of the saintly to God, not only in soul but in body as well, so that the elected are one in God (cf. Haren 1985:79) when nothing animalistic, bodily, human or natural remains. Conscious of the contentiousness of a concept such as deification, Eriugena nevertheless preserves the use of the concept in order to guarantee the continued and distinguishable existence of the individual soul. Although he hereby succeeded in maintaining both the Christian notion of the immortality of the soul and the Neoplatonic-mystical ascension of the soul, the concept led to much confusion and an alienation from Augustinian theology. But more importantly, this concept played a crucial role in the repeated condemnation of the Periphyseon, namely, that Eriugena's understanding of 'nature', in terms of cosmic reditus, was considered to be pantheistic (cf. Haren 1985:80). Well aware that his system could be interpreted as indeed pantheistic, Eriugena was nevertheless convinced that the Neoplatonic emphasis on the transcendence of the One would counter that interpretation. Because he employed a jargon in several other contexts in the Periphyseon that indeed could insinuate a pantheistic affinity, the work in the end could, however, not escape the impression that it was fundamentally pantheistic. It was mainly on the basis of this skewed impression that the work was finally condemned in 1225 by Pope Honorius III. ${ }^{5}$

5.As the objective of this article is not to present technical analyses of manuscript development in Eriugena's oeuvre and the historical development of Eriugena's reception in the central and later Middle Ages, it does not dwell on these issues in the main text. After considering an anonymous peer reviewer's valid and relevant comments in this regard (hereby with acknowledgement), Honorius Augustodunensis' (ca.1080-1154) Clavis Physicae (see Honorius Augustodunensis 1974) as Eriugena's veiled 12th-century disseminator and the complexities surrounding the Paris Manuscript (see footnote 3 ) should be briefly addressed. Even though the Periphyseon was, thus, already condemned by 1210 , the work was known primarily through the Augustodunensian 'paraphrase' (Lahey 2020:448) and 'awn primmary' (Ough the Augustodunensian 'paraphrase' (Lahey 2020:448) and 'astute summary" (Otten 2020a:189) of it in the Clavis Physicae (written already circa 1125), whereby in its first part Augustodunensis (1974:1-315) summarises the first four volumes and in its second part he (Augustodunensis 1974:316-529) presents treatise on the fifth volume of the Periphyseon. Notwithstanding Augustodunensis dissemination of the Periphyseon in the Clavis Physicae, the work was indeed (with few exceptions, e.g., Nicholas of Cusa's engagement of it in the 15th century) not 'read and studied much until the publication of its first print edition in 1681 by Thomas Gale, the original of which based on ms. Trinity College 0.5 .20 can be found in Cambridge's Trinity College library' (Otten 2020a:189). It was Gale's edition that was put on the Index of Prohibited Books in 1684. Eriugena's official condemnations can, thus, be nuanced by the creative ways that his thought still continued in some circles from the 12th century onwards (cf. Kijewska 2020:349-386) and well into modernity, for example, in the phenomenological tradition (Moran 2014:601-636). For many years, the main edition of the Periphyseon was the Patrologia Latina edition (PL 122) edited by H.J. Floss in 1853 as De divisione naturae. The current critical edition is Periphyseon, Volumes I-V, under the editorship of E.A. Jeauneau in Corpus Christianorum Continuatio Mediaevalis 161-165, Brepols, Turnhout. Fo Corpus Christianorum Continuatio Mediaevalis 161-165, Brepols, Turnhout. For translations, see I.P. Sheldon-Williams (ed. \& transl. 1968, 1972, 1982) and J.J. Orans translations, see Periphyseon (The Division of Nature), 1.P. Sheldon-Williams (transl.), revised by J.J. O'Meara, 1987 (out of print), Montreal, Bellarmin \& Washington, Dumbarton Oaks; and John the Scot, Periphyseon on the Division of Nature, M.L.
Uhlfelder (transl.), J.A. Potter (intr.), 1976, reprint 2011, Eugene OR, Wipf and Stock.
Fourteen extant works can with certainty be ascribed to Eriugena, as listed in the published proceedings of Society for the Promotion of Eriugenian Studies (SPES) (see infra; cf. Corrazon 2019:1):

- De divinae praedestinatione ('On divine predestination'; ca. 850-851);

- In Priscianum (also known as the Glosae Prisciani; ca. 850);

- Annotationes in Marcianum (ca. 840-850);

- Glosae Martiani (ca. 840-850);

- Glossae divinae historiae (850-860);

- Versio operum sancti Dionysii Areopagitae (the mentioned translation of the works of Pseudo-Dionysius, completed before 860-864);

- Versio sancti Gregorii Nisseni Sermonis de imagine (the translation of Gregory of Nyssa's On the Image of Man; 862-864);

- Versio sancti Maximi Confessoris Ambigua ad lohannem (the translation of Maximus Confessor's Ambigua to John; 862-864);

- Versio sancti Maximi Confessoris Quaestiones ad Thalassium (the translation of Maximus Confessor's Questions to Thalassius; 864-866);

- Periphyseon I-V (864-866);

- Expositiones in hierarchiam caelestem (an exposition on The Celestial Hierarchy ${ }^{6}$ of Pseudo-Dionysius; 864-870);

- Vox spiritualis aquilae (Sermon on the Prologue to the Gospel of John; 870-872)

- Commentarius in Iohannem ('Commentary on the Gospel of John'; 875-877)

- Carmina ('Poems'; 850-877).

The majority of these works were systematically disseminated by members of SPES over the past five decades, as indicated infra.

\section{The founding (1970) of Society for the Promotion of Eriugenian Studies and its contributions over the course of five decades (2020)}

After the expiration of the Index of Prohibited Books in the 1960s, and disseminations of and commentaries on the Periphyseon started circulating in the aftermath of early 20th-century specialist analyses, such as the mentioned works of Cappuyns (1933) and Bett (1925), it became evident in Ireland itself that more systematic work ought to be done to comprehensively rehabilitate the legacy of this for centuries neglected Irish thinker. In 1970, the Society for the Promotion of Eriugena Studies was established with the sole objective to reappraise Eriugena's significant contribution to the development of the Western history of ideas. With a guaranteed stipend of the Royal Irish Academy and a publication subsidy of The Dublin Institute of Advanced Studies, a massive undertaking was launched: all five volumes of the Periphyseon were to be edited, translated and

6. Eriugena's commentary on The Celestial Hierarchy may very well have been the first Latin Christian commentary on a non-scriptural writing (cf. McEvoy 1987:201). 
annotated in English. ${ }^{7}$ The acclaimed Medieval specialists Inglis Sheldon-Williams, ${ }^{8}$ John O'Meara and Ludwig Bieler took the initiative in the creation of SPES at the occasion of the first international Eriugena conference in Dublin in July 1970, which was presented under the hefty title The Mind of Eriugena. By 1995, four of the five volumes were translated: The first three volumes ${ }^{9}$ were edited and translated by Sheldon-Williams, assisted by Ludwig Beier, with editorial intervention by John O'Meara after Sheldon-Williams' death in 1973, again assisted by Beier. O'Meara's contribution was extensive: he re-edited all SheldonWilliams' (handwritten) translations and annotations with regard to the first three volumes and had the work published under Sheldon-Williams' editorship. O'Meara, henceforth, completed the translation and annotation of the fourth volume under the editorship of Edouard Jeauneau (ed. 1995), out of which was born one of the most distinguished Eriugenamonographies from Ireland itself (O'Meara's Eriugena, 1988).$^{10}$

The editing and translation of Volume $\mathrm{V}$ under the editorship of Jeauneau was completed in 2003. It is worth noting that the enigmatic Pope Benedict XVI presented Jeauneau with a papal coat of arms as a token of appreciation on the successful conclusion of the project. Benedict XVI (Joseph Aloisius Ratzinger, b. 1927, pope from 2005 to 2013) himself was a bona fide Eriugena-researcher, as was confirmed by his assessment of Eriugena's significance in a general audience on Saint Peter's Square on Wednesday 10 June $2009 .{ }^{11}$ It is a painful yet uplifting irony that a thinker whose primary text was for more than five centuries barred from church and society, burnt and put on the Index of Prohibited Books at last was rehabilitated in the philosophical labour of a brilliant 21st-century pope.

After its inception, SPES immediately went to work to introduce Eriugena thoroughly into the Irish public sphere. Because no

7.It is nevertheless important to pertinently distinguish SPES's work from the Dublin Institute's support of Sheldon-Williams' translation of the Periphyseon. This translation and SPES' foundation in 1970 are clearly related but should be kept apart; rather, they 'can be described as siblings in Eriugena's revival' (acknowledging an anonymous reviewer's comment in this regard).

8.The other 'SPES-members of the first hour' (eds. Otten \& Allen 2014:ii), Pádraig Ó Cléirigh Edouard Jeauneau, Werner Beierwaltes, Gustavo Piemonte and Breandán Ó Cíobháin, Edouard Jeauneau, Werner Beierwaltes, Gustavo Piemonte and Breandán O Cíobf
were pivotal figures in the first three decades of SPES' work from 1970 to 2000.

9. Referring to Sheldon-Williams' (ed. \& transl. 1968, 1972, 1982, 1995) groundbreaking contributions.

10.Among the strengths of O'Meara's monography is its translation of Eriugena's Vox spiritualis aquilae (Sermon on the Prologue to the Gospel of John; dated 870-872). However, three shortcomings of the work could be pointed out: 'While O'Meara (1988:60[nt.26]) indicated that his discussion of Pseudo-Dionysius "is much indebted" to R. Roques's articles in Dictionnaire de spiritualité, he does not acknowledge that the discussion is a translation of these articles'. Secondly, 'in his ong summary of the Periphyseon O'Meara (1988:80[nt.1]) noted that "(M)uch use is made [...] of I.P. Sheldon Williams' translation," but he does not acknowledge that this summary (in O'Meara 1988:80-154) is little more than an edit of SheldonWilliam's translation'. Thirdly, 'by ignoring the Periphyseon's dialogue form' O'Meara compressed an already dense text 'into a highly technical treatise' (with acknowledgement to an anonymous reviewer's critical interpretation of and irrefutable comments on O'Meara's text).

11.For the full text of Benedict XVI's assessment of Eriugena published with the permission of Libreria Editrice Vaticana, see Guiu (2020a:454-457).

12.The Central Bank of Ireland issued the Irish Pound 'B Series' banknotes in eight different denominations in 1976, including this $f 5$ note featuring Eriugena: on the obverse, the letter A from the start of Psalm 17 of the Psalter of Ricemarch (an 11thcentury Welsh illuminated psalter) was used against the Book of Durrow (the oldest extant complete illuminated insular Gospel book, with the manuscript present at Durrow Abbey by 916; now ms. A.4.5.[57], held at Trinity College, Dublin), while the reverse featured an adaptation of animal and script extracts from the Book of Kell (an illuminated manuscript Gospel book in Latin, ca.800, ms. A.I. [58], held at Trinit College, Dublin). These 'B Series' banknotes were withdrawn from circulation in 1993. Acknowledgement and copyright https://oldcurrencyexchange.

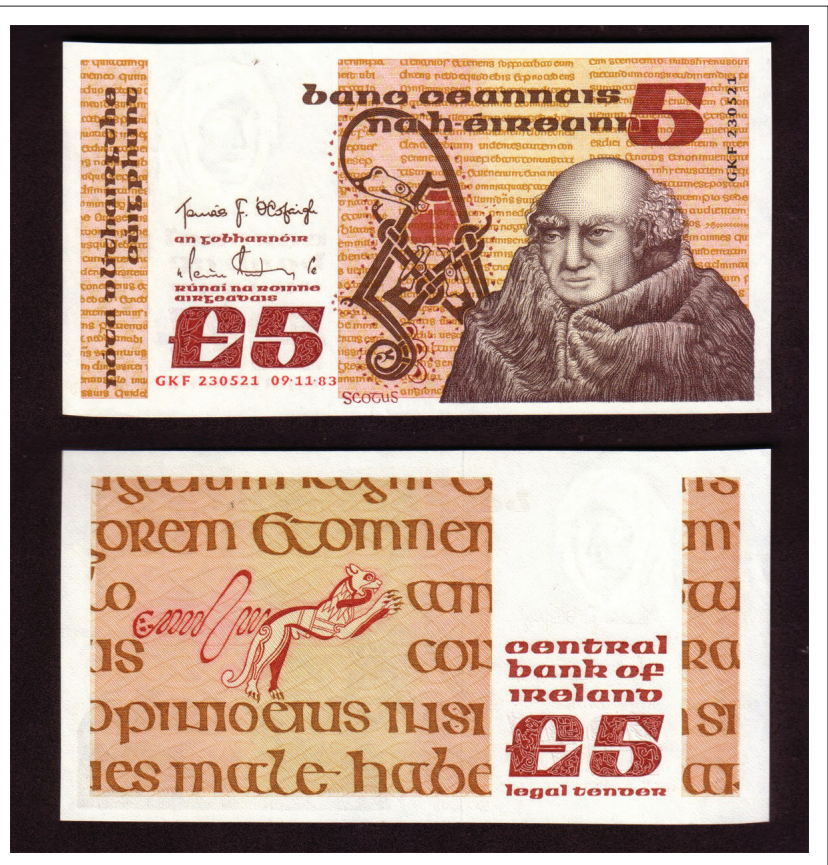

Source: Oldcurrencyexchange, n.d., O'Brien Banknote Guide: Five Pounds, Irish Banknote 'B Series' viewed n.d., from https://oldcurrencyexchange.com/2015/07/13/obrien-banknote FIGURE 1: Scotus, Central Bank of Ireland's f5, in use from 1976 to $1993 .^{12}$

paintings of Eriugena were produced after 1225, graphics from the first copies of manuscripts of the Periphyseon were recreated, resulting in a single, relatively realistic facial image of Eriugena, which was printed on the Central Bank of Ireland's $£ 5$ note, in use up to 1993 (Figure 1). Featuring the single word Scotus ('from Ireland'), this creative neo-reception took care that a name not mentioned, a face not seen and a voice not heard for centuries could become visible and audible in Ireland and beyond.

Society for the Promotion of Eriugenian Studies' attempts to publish specialist outputs on Eriugena over the past five decades are already bearing fruit in the quality of juxtaposed readings of Eriugena and other Neoplatonic thinkers, as reflected in the most recent research (cf. Harrington 2020:64). Relatively young as the Eriugena-niche still is, compared to that of John Duns Scotus or William of Ockham, for example, it has a bright future precisely because of SPES' efforts: Eriugena certainly is no longer the (Otten \& Allen 2014):

$[M]$ isunderstood Irish genius whose idiosyncrasies could give rise to false charges of heresy but should instead be regarded as an integral part of a longer list of Medieval intellectuals populating the intellectual landscape of the Medieval West [...]. (p. x)

The rehabilitating efforts of SPES from July 1970 to 2014 can be deduced from the published proceedings of its 11 conferences up to date: ${ }^{13}$

13.SPES established a website (https://eriugenaspes.org/about/) in 2019 as a new means to spread the word about the revival in Eriugena scholarship. Although a short framework of its 11 conferences is provided in the website, it does not
provide any details about the contents of the proceedings nor the extensive contributions of individual SPES members. However, the individual contributions at every conference are now listed at https://www.ontology.co/biblio/eriugenaeditions.htm (by Corrazon 2019:18-24). The author verified the correctness of these listings from the published proceedings as such: rather than duplicate the individual contributions here, the reader is referred to the above link and page individual contributions here, the reader is referred to the above link and page
range. The author's inferences in the following paragraphs can be verified range. The author's inferences in
according to this information as well. 
Conference I: 14-18 July 1970

Proceedings published as: O'Meara, J.J. \& Bieler, L. (eds.), 1973, The Mind of Eriugena, Papers of a Colloquium on Eriugena, Dublin, 14-18 July 1970, Irish University Press, Dublin.

\section{Conference II: 7-12 July 1975}

Proceedings published as: Roques, R. (ed.), 1977, Jean Scot Erigène et l'histoire de la philosophie, Actes du II Colloque International, Laon, 7-12 juillet 1975, Éditions du Centre national de la recherche scientifique, Paris.

Conference III: 27-30 August 1979

Proceedings published as: Beierwaltes, W. (ed.), 1980, Eriugena. Studien zu seinen Quellen, Abhandlungen der Heidelberger Akademie der Wissenschaften. Philosophisch-historische Klasse, Vorträge des III. Internationalen Eriugena-Colloquiums, Freiburg im Breisgau, 27-30 August 1979, Carl Winter, Heidelberg.

Conference IV: 28 August-02 September 1983

Proceedings published as: Allard, G-H. (ed.), 1986, Jean Scot Écrivain, Actes du IV Colloque international, Montreal, 28 aout -2 septembre 1983, Vrin, Paris.

Conference V: 26-30 August 1985

Proceedings published as: Beierwaltes, W. (ed.), 1987, Eriugena Redivivus: Zur Wirkungsgeschichte Seines Denkens Im Mittelalter Und Im Übergang Zur Neuzeit, Abhandlungen Der Heidelberger Akademie Der Wissenschaften, Philosophisch-Historische Klasse, Vorträge des V. Internationalen Eriugena-Colloquiums, Werner-Reimers-Stiftung, Bad Homburg, 26-30 August 1985, Carl Winter, Heidelberg.

\section{Conference VI: 11-14 October 1985}

Proceedings published as: Leonardi, C. (ed.), 1989, Giovanni Scoto Nel Suo Tempo: L'organizzazione Del Sapere in Età Carolingia, Atti del VI. Convegno storico internazionale, Todi, 11-14 ottobre 1987, Centro italiano di studi sull'Alto Medioevo, Spoleto.

\section{Conference VII: 26-29 July 1989}

Proceedings published as: Beierwaltes, W. (ed.), 1990, Begriff und Metapher: Sprachform des Denkens bei Eriugena, Abhandlungen Der Heidelberger Akademie Der Wissenschaften, Philosophisch-Historische Klasse, Vorträge des VII. Internationalen Eriugena-Colloquiums, WernerReimers-Stiftung, Bad Homburg, 26-29 Juli 1989, Carl Winter, Heidelberg.

\section{Conference VIII: 18-20 October 1991}

Proceedings published as: McGinn, B. \& Otten, W. (eds.), 1994, Eriugena: East and West, Papers of the VIII International
Colloquium of the Society for the Promotion of Eriugenian Studies, Chicago and Notre Dame, 18-20 October 1991, University of Notre Dame Press, Notre Dame, IN.

Conference IX: 07-10 June 1995

Proceedings published as: Van Riel, G., Steel, C. \& McEvoy, J. (eds.), 1996, Iohannes Scottus Eriugena: The Bible and Hermeneutics, Proceedings of the IX International Colloquium of the Society for the Promotion of Eriugenian Studies held at Leuven and Louvain-la-Neuve, 7-10 June 1995, Leuven University Press, Louvain.

Conference X: 16-20 August 2000

Proceedings published as: McEvoy, J. \& Dunne, M. (eds.), 2002, History and Eschatology in John Scottus Eriugena and His Time, Proceedings of the $X$ International Conference of the Society for the Promotion of Eriugenian Studies held at Maynooth and Dublin, 16-20 August 2000, Leuven University Press, Louvain.

Conference XI: 9-12 November 2011

Proceedings published as: Otten, W. \& Allen, M.I. (eds.), 2014, Eriugena and Creation, Instrumenta Patristica et Mediaevalia 68, Proceedings of the XI International Conference on Eriugenian Studies, held in honor of Édouard Jeauneau, Chicago, 9-12 November 2011, Brepols, Turnhout (cf. https://eriugenaspes.org/about/).

The above conference proceedings of SPES indicate the commitment of the members of the society, over a period of more than four decades, to disseminate and illuminate the thought of a Medieval thinker who, up to the 1960s, was effectively absent in modern Medieval research. In addition, SPES is evidently an international academic society which transcends its initial Irish embeddedness, with contributions at these conferences presented in English, French, German and Italian, hosted on both continents across the Atlantic, with Ireland nevertheless at its idea-historical and geographical centre.

Although every presentation at the 11 conferences was unique in its own way and every participant's offering of course appreciated, the above conference proceedings enable an isolation of key historical figures in SPES' functioning, with specific reference to consistent outputs at those conferences. The following members presented four or more papers at the 11 conferences or were additionally involved in the organisation thereof: Guy-H Allard, Werner Beierwaltes, Deirdre Carabine, John Contreni, Marta Cristiani, Giulio d'Onofrio, Donald Duclow, Stephen Gersh, Michael Herren, Édouard Jeauneau, Claudio Leonardi, James McEvoy, Bernard McGinn, Dominic O'Meara, John O'Meara, Willemien Otten, Gustavo Piemonte, Gangolf Schrimpf and Carlos Steel. Other eminent 20th-century and contemporary scholars of Medieval philosophy who contributed to the conferences on a somewhat lesser scale include Arthur 
Hilary Armstrong, Yves Christe, Robert Crouse, Peter Dronke, Paul Dutton, Alois Haas, Agnieszka Kijewska, Hans Liebeschütz, Goulven Madec, John Marenbon, Jack Marler, Rosamond McKitterick, Dermot Moran, Jean Pépin and Eric Perl. Ludwig Bieler was the society's first honorary president, followed by presidents John O'Meara (1970-1975), René Roques (1975-1979), Werner Beierwaltes (1979-1983), Guy-H Allard (1983-1987), Claudio Leonardi (1987-1991), Bernard McGinn (1991-1996), Carlos Steel (1996-2000) and James McEvoy (2000-2010). Willemien Otten has headed SPES with solemn efficiency since 2011, assisted by Ernesto Sergio Mainoldi. ${ }^{14}$

The thematic comprehensiveness of the dissemination of Eriugena's thought in SPES' labour is striking, including juxtapositions (with, amongst others, Augustine, PseudoDionysius, Maximus Confessor, both Hugo and Richard of Saint Victor, Martianus Capella, Marius Victorinus, Hildegard von Bingen, Robert Grosseteste, Meister Eckhart, Nicholas of Cusa, Honorius Augustodunensis, Schopenhauer, Hegel and Wittgenstein), extensive commentaries on the Periphyseon, Eriugena's Greek and Neoplatonist sources, metaphysics, literary analyses, negative theology, mystical theology, Christology, predestination and human freedom, causation, creation, eschatology, Eriugena's metaphors, theophany, anthropology, psychology, hermeneutics, translations, poetry, mathematical concepts, musicology, art, socio-historical analyses of the Carolingian period and the Carolingian schools, Eastern patristic thought and its influence on Eriugena, metaphors and symbolism, the philosophical importance of grammar and Eriugenian ontology - to isolate just a few of the prominent strands that manifested itself over the course of the 11 conferences. The date for Conference XII of the Society for the Promotion of Eriugenian Studies has not yet been confirmed.

\section{A Companion to John Scottus Eriugena, Brill, Leiden, 2020}

In the meantime, SPES' work over the past five decades is implicitly extended, if not celebrated, in a brilliant editorial work, A Companion to John Scottus Eriugena, published in the year ${ }^{15}$ of SPES' 50 -year jubileum by Brill in Leiden, under the editorship of Adrian Guiu. Although the work is expressly not a formal publication of the society itself, it is clear from the acknowledgements, abbreviations for commonly cited secondary sources and introduction (cf. Guiu 2020c:1-6) that the work is highly indebted to the SPES' conferences, as expounded supra. The work focuses on the:

$[P]$ recedents of Eriugenian scholarship by mapping extant and potential new perspectives on Eriugena's work, including the Christological dimension of his thought, the correspondence

14.A brief overview of the history of its administration can be viewed at hittps:// eriugenaspes org/about/, while a list of the current and former members of SPES can be viewed at https://eriugenaspes.org/members/ (accessed on 12 April 2021).

15. Although the official date for publication is indicated as 21 October 2019 for the e-book and 24 October 2019 for the hardback (per https://brill.com/view/ title/39179), the copyright page in the hardback (ISBN 978-90-04-38267-1) states title/39179), the copyright page in the hardback (ISBN 978-90-04-38267-1) states
'Copyright 2020 by Koninklijke Brill NV, Leiden, The Netherlands' and is presented here as such. between theology-dialectic-philosophy, the thinkers and works that have influenced the thought of Eriugena, and finally the impact of Eriugena's ideas in the Middle Ages and modernity. (pp. 1-2)

The renowned publisher Brill and the main editor of the series 'Brill's Companions to the Christian Tradition', Christopher M. Bellitto, must be commended for yet another publication from this magnificent series, which brought, once again, a marginalised Medieval thinker from the discursive shadows of the history of ideas into mainstream research in Medieval philosophy. A Companion to John Scottus Eriugena explicitly conforms to SPES' main objective, namely, to highlight the unique contributions of Eriugena as a 'multifaceted thinker, teacher and writer' (Guiu 2020c:1) and can in this sense be connected to SPES' work.

A Companion to John Scottus Eriugena consists of four parts: (1) a contextualisation of Eriugena's life, influences and work; (2) perspectives on the Periphyseon as such; (3) the lesser known and pertinently theological implications of Eriugena's works (titled 'The Other Eriugena'); and (4) Eriugena's influence on developments in the Western history of ideas (notably on the 12th century before the final condemnation of Periphyseon, resonances of the Periphyseon in the Renaissance and the reception of Eriugena in modern scholarship).

With regard to the contextualisation of Eriugena in the first section of the volume (cf. Guiu 2020c:2), Alfred Siewers' (2020:9-30) 'Eriugena's Irish Background' argues (2020:9) that Eriugena should first and foremost be engaged from his Irish context, even though, for a number of reasons Siewers points out, the tendency in the reception has been to 'discourage active emphasis on his Irishness'. Siewers (2020:9) consequently 'attempts to outline a more cosmopolitan textual milieu for (Eriugena's) work, both in terms of his native culture and his work's related Eastern Mediterranean affinities'. John Contreni's (2020:31-63) 'John Scottus, Nutritor, and the Liberal Arts' surveys the intellectual setting at the Carolingian court from the 840s onwards, indicating that Eriugena's most significant contribution was that he advanced the liberal arts into philosophy pura et vera, as true wisdom, in his fusion of the speculative systems of Pseudo-Dionysius, Maximus Confessor and Augustine. Michael Harrington's (2020:64-92) extensive contribution, 'Eriugena and the Neoplatonic Tradition', accentuates Eriugena's thought as a beacon of Neoplatonic reception and neo-interpretation in the Latin West, which utilised several Neoplatonic sources (Gregory of Nissa and Maximus in particular, starting, however, with Eriugena's understanding of Plato himself, whilst stressing that Eriugena never referred to the original Neoplatonists Plotinus or Porphyry as such, Harrington 2020:65) in its attempt to re-address some fundamental philosophical questions associated with Christian dogma and tradition in the 9th century. Via these thinkers Eriugena:

$[H]$ ad access to the major themes of Neoplatonism: its division of a sensible from an intelligible reality, and its division of the 
intelligible reality into the now familiar components of the One, the Intellect and the Soul $[\ldots]$ the Neoplatonists could provide him with the position that the world we experience through our senses is dependent for its existence on a world we experience through the intellect. (pp. 64-65)

Harrington (cf. Guiu 2020c:2), henceforth, argues that the single idea defining Eriugena's originality is that all creatures have their being completely in God, indicating that Eriugena's analysis of the relation of cause to effect brought him to the conclusion that all creatures have their formal being in the primordial causes (that is, in God) as well as that the perceptible effects of these creatures are real within God: this conclusion, of course, negates the fundamental Augustinian divide between creator and creature, thereby shifting the established concept of the soul's being from a lesser spiritual being, dependent on the divine ideas for its reality, to an effective equal of those perfect intelligible beings. Harrington shows that Eriugena, in this sense, employed Neoplatonic reasoning precisely to transcend standardised Neoplatonist frames of reference (cf. Guiu 2020c:2). The last offering in the volume's first section, Christophe Erismann's (2020:93-110) 'Between Greek and Latin: Eriugena on Logic', takes its premise from the 'close and mutually beneficial relation between logic and theology', which was in Eriugena's time already 'an established tradition of rational theology' (Erismann 2020:93). Erismann consequently juxtapositions Eriugena's thought with the Latin logical tradition of Porhpyry, Martianus Capella and Boethius and provides an in-depth analysis of how Eriugena presented a fusion of this tradition with the Greek logical tradition, as it was carried forward in the early Middle Ages by Maximus. As a logical realist Eriugena should in terms of Erismann's reading be considered an authentic developer of both traditions in his unique amalgamation of exegesis, logic and metaphysics (cf. Guiu 2020c:2).

The second section in the volume (cf. Guiu 2020c:2-4), thus, deals with the Periphyseon as such. With her 'A Thematic Introduction to and Outline of the Periphyseon for the Alumnus', Elena Lloyd-Sidle (2020:113-133) provides an accessible summary of the complex argumentation in the Periphyseon for a non-specialised readership, including a thematic outline of the work. She also considers the close relation between style and content in the Periphyseon, given that for Eriugena 'all levels and aspects of reality are essentially linked', noting that (Lloyd-Sidle 2020):

$[O]$ ne gets the sense that Eriugena is playfully expressing the content through his method [...] (T)he reader is never allowed to rest too long on one aspect of reality, but is always reminded that one aspect comes from and leads to others. (p. 114)

John Gavin's (2020:134-153) ‘A Theologian's Itinerary: John Scottus Eriugena's Christological Ascent' resists by point of departure the modernist tendency to rigidly distinguish between philosophy, mysticism, literary theory or exegesis and theology, thereby tending to afford Eriugena a single area of specialisation. Eriugena was as much a philosopher as a mystic and theologian and, therefore, evades these single clusters of occupation. However, in terms of 'vocation' (Gavin 2020:134) Eriugena could best be described as a 'theologian', where theologia and theoria are integrated in 'a journey that unites the speculative and contemplative' (Gavin 2020:135). For Eriugena, Gavin argues, this journey 'has a very specific form and guide', which is Christ, the incarnate Word - because only Christ 'unites in man both the speculative and participative' (Gavin 2020:135). Gavin stresses that Eriugena is often read and discussed from a modern perspective as a 'philosopher' who excelled in synthesising Greek theology and Latin metaphysics, whilst he (as by far the majority of Medieval thinkers from the 5 th to the 15th century) was 'by vocation' a theologian, in Eriugena's case, thus, a fundamentally Christ-centred one who presupposed the mediation of Christ in the human relation to God. Gavin isolates the Christological features in Eriugena's thought, thereby reappraising Eriugena's profound Christian identity, in an implicit critique of the repeated theological condemnations of the Periphyseon up to 1225 . This accessible introduction to the theological features and implications of the Periphyseon significantly associates the incarnation of the Word in Christ with the fulfilment of the divine ideas in all creatures, thus as a 'quasi-Incarnation' (Guiu 2020c:3) which, when comprehended, enhances a 'rational understanding of creation' (Guiu 2020c:3) where the fallen intellect is enabled to understand the ultimate concord of faith and reason in theology. It was for this very reason that Pope Benedict XVI (see Guiu 2020a:454-457), as previously mentioned, rehabilitated Eriugena's theology in the life and work of the church, characterising it as the most evident attempt to express the expressible of the inexpressible God based solely on the mystery of the Word made flesh' (Guiu's reference 2020c:3 [fn.1 as well]). In proximity to Gavin's reading, renowned Medieval scholar Bernard McGinn (2020:154-188) presents the Periphyseon as 'hexaemeral commentary', focusing on Eriugena's 'exegesis in practice' by using his interpretation of the first three chapters of Genesis as example - because these three chapters feature extensively in the Periphyseon. McGinn (2020:154) indicates that it is, in fact, not possible to sharply divide between Eriugena's exegetical theory and practice (as it is, e.g., possible with Augustine with reference to his De doctrina christiana), with the consequence that his 'norms for reading the Bible' have to be distilled from his hexaemeral commentary. In addition, the Periphyseon (McGinn 2020):

[T] eaches that it is within the very work of struggling to understand what the Bible has to say about the nature of God, humanity, and the cosmos that the 'return' (reditus) to union with God is affected. (p. 154)

McGinn, henceforward, shows that Eriugena's exegesis of Genesis employed both Basil the Great and Gregory of Nyssa from the East, and Ambrose and Augustine from the West, in his own reflections on creation. Eriugena's fourfold division of being, as discussed earlier, enables him to use the relevant passages in Genesis to stress the close relation between the creating agent ('created being that creates') and the created 
subject ('created being that does not create'). McGinn highlights Eriugena's cautious approach in his interpretation of the words of Genesis: 'just like creation itself, Scripture reflects the structure of God's thought within itself' (Guiu 2020c:3), an illustration of a basic feature of Eriugena's thought, namely, that reason and Christian dogma are 'commensurate' and fundamentally 'in concord' (Guiu 2020c:3). Current SPES President Willemien Otten (2020a:189-212), in her 'Suspended between Cosmology and Anthropology: Natura's Bond in Eriugena's Periphyseon', introduces the relevance of the relation between Eriugena's cosmology and anthropology by initially focusing on the way the condemnation of the Periphyseon in 1225:

[S]everely hindered Eriugena's integration into a larger history of thought, not only medieval but also beyond; for while certain elements of his cosmology and anthropology are undoubtedly present in medieval thought, their presence cannot be attributed primarily to Eriugena's particular articulation. (Otten 2020a:190)

Otten then scrutinises the fundamental concept of Natura showing that 'Eriugena's understanding of the relation of creator to creation, as well as the role of human reason in completing this relation', centred around this concept (Guiu 2020c:3-4). Eriugena's anthropology is for Otten crucial, because with the creation of humanity reditus, the return to the creator also begins. Eriugena's anthropology is in this sense not only 'teleological', in the sense that it intrinsically points towards the conclusion of creation but also the medium by which reditus can be realised. Humanity's reason, thus, plays a decisive part in completing the emanational process of created Natura's completion in its return to the creator. ${ }^{16}$ Giulio D'Onofrio's (2020:213-240) 'The speculative system of John Scottus Eriugena and the tradition of Vera Philosophia' departs from what could be considered as one of Eriugena's fundamental epistemological considerations: '[t]rue knowledge [...] produces an indissoluble unity - and therefore a complete identity - between the substantial reality of the subject and that of the object': this coming together of the knowing subject and the known object in a single realm is, according to Eriugena, 'the prerogative of the purus intellectus: "The pure intellect is that which becomes what it knows"' (D'Onofrio 2020:213). Against this background, D'Onofrio (2020) investigates Eriugena's inquiry into the intellect's understanding of other ('angelic') creatures and the role of (co-)participation in this regard:

When two intelligences $[\ldots]$ communicate in a single language that both understand, they question, they examine and they know one another. In this way they acquire a shared comprehension of the same object. Each subject of true knowledge thus becomes a single entity with either the other subjects who participate in the knowledge, or with the object itself that they know. (pp. 213-214)

Eriugena comes to the conclusion that reason alone is unable to reach a true and accurate presentation of the fundamental reality of things and that the only way to understand nature

16.0tten's (2020b) recent illumination of Eriugena via Augustine and Maximus in several gripping expositions in Thinking Nature and the Nature of Thinking: From
Eriugena to Emerson (Stanford University Press, 2020) should in this context be mentioned as well. is to procure the intellectual identity with the first subject of every truth, namely, the divine essence engaged in the perfect knowing act (cf. Guiu 2020c:4); in other words, 'the true being of any given creature is removed from the mind's grasp because it is rooted in its creator' (Guiu 2020c:4).

The third section of A Companion to John Scottus Eriugena (cf. Guiu 2020c:4-5), thus, engages the 'lesser known' or 'Other Eriugena'. In the 9th century, when the 'Latin fathers were the only Christian authorities' (Guiu 2020c:4-5) in the West, apart from the Biblical texts, Eriugena distinguished himself precisely in terms of his commitment to provide a distinctive fusion of Greek and Latin patristic theology and to disseminate Pseudo-Dionysius, Maximus Confessor and other Eastern sources, such as Epiphanius of Salamis, the Cappadocians and Origen. His translations and interpretations of these sources 'opened for him philosophical and theological vistas unavailable in Latin theology' (Barstad 2020:267). Against this backdrop, Joel Barstad's (2020:267-295) 'Eriugena as Translator and Interpreter of the Greek Fathers' provides insight into the complexity of Eriugena's amalgamation of East and West, of Greek and Latin theology, in which Dionysius, Maximus and the Cappadocians are constantly alternated with Augustine:

Throughout Eriugena's progressive encounter with the Greeks, Augustine's speculations regarding eternity, time, and history, in relation to the single act by which God created everything all together and at once, remain the starting point for Eriugena's thought on the Creator-creature relation. (Barstad 2020:267)

With Augustine constantly in the picture as a sort of tallying presence from the West, Eriugena's interpretation of creation nevertheless became infused with the concept of theophany, ${ }_{17}^{17}$ a sensical confirmation of the presence of God, especially with regard to his understanding of matter and corporality. Barstad (2020:268) shows that even within the context of the dominance of this 'Greek' concept, it would not be correct to deduce that Eriugena 'adopted a simple, partisan loyalty to Greek theology over Latin'. Rather, by establishing an Augustinian platform prior to his engagement with the Greek sources, which provided him with a 'core which his major Greek sources enable(d) him to defend and develop', Eriugena stepped forward as 'an original thinker and creative interpreter of the several traditions to which he adds his voice' (Barstad 2020:268). Precisely within the context of theophany, editor Adrian Guiu's (2020b:296-325) own contribution to the volume, apart from his eloquent introduction, 'Eriugena reads Maximus Confessor: Christology as Cosmic Theophany', elaborates on how dealing with Maximus' legacy had as a 'kairotic moment' (Guiu 2020b:296) a profound impact on Eriugena's understanding of the role of the human being as the 'workshop of creation' (Guiu 2020c:5) and his reflections on

17.For the way Eriugena synthesises Augustine and Pseudo-Dionysius regarding theophany, see Eriugena (1996-2003, Periphyseon III:685A: Corpus Christianorum theophany, see Eriugena (1996-2003, Periphyseon III:685A; Corpus Christianorum Continuatio Mediaevalis 163:94); Otten (2013:938-941); Hankey (1998:125-160) and D'Onofrio (1994:115-140). Eriugena's teachings on theophanies may also be considered to be a 'key reason why the Periphyseon was increasingly considered suspect': see the 1241 and 1244 condemnations of the University of Paris Chartularium Universitatis Parisiensis, Volume I, \#128, [ed. Denifle 1889]; for an explanation of these, see Tugwell 1988:51-52; with acknowledgement of an anonymous peer reviewer's comment in this regard). 
creation via his reading, in the footsteps of Basil the Great's hexaemeral interpretation, that is, of the first three chapters of Genesis in particular. Significantly Guiu focuses on Eriugena's Christology, still a rather neglected aspect of his legacy, by arguing that the reconciliation of anthropological and Christological vistas provides a form of hermeneutic stability in Eriugena's work. Guiu (2020b:296-297) does this by isolating three ideas of Maximus that he considers to be at the core of Eriugena's thought: (1) the anthropology of the officina omnium which Guiu (2020b:296-297) isolates as central in the Periphyseon, which points to the dialogical 'spiritual exercise of training and conversation through the liberal arts in order to contemplate nature in the right way in order to achieve a unified vision of creation', resulting in Eriugena's 'grand attempt of reading the two books in which the divine is theophanically displayed (namely) creation and scripture' (Guiu 2020b:296-297); (2) Eriugena's inventive method (physiologia) in the Periphyseon, whereby natural philosophy and exegesis are used reciprocally and ultimately fused in a single orientation, has its roots also in Maximus; and (3) the Maximian notion of the divine revelation in Christ as a cosmic mediation and unification of creation. Guiu (2020b:298-325), henceforth, argues that Maximus' cosmic incarnation 'constitutes the ultimate horizon of Eriugena's theophanic creation' (although the notion of theophany is originally Dionysian, it is 'enhanced through Maximus' incarnational cosmology'; Guiu 2020b:297). Guiu, thus, takes up the difficult task of addressing the question how 'the centrality of Christology and of the incarnation can be harmonized with other aspects of the Periphyseon' (Guiu 2020b:297). Tackling the difficult theme of predestination with its many and disagreeing versions in the history of theology, the current secretary of SPES, Ernesto Mainoldi (2020:241-266), in his 'Eriugena's Intervention in the Debate on Predestination', argues that Eriugena's earlier involvement in the (in)famous debate initiated by Charles the Bald's advisor, Archbishop Hincmar of Rheims (806-842) and engaged by the Saxon monk Gottschalk of Orbais (ca.808-868) regarding the latter's teaching of twofold predestination (gemina praedestinatio; that is, some people are created to be saved and others to be damned) and its relation to free will and which around 851 manifested in Eriugena's De Predestinatione indicate that Eriugena already had grounded his theological position and carved out a rather problematic position for himself almost a decade before work on the Periphyseon commenced. In a meticulous analysis of Eriugena's text, Mainoldi shows why the reaction against Eriugena (including that of Hincmar) was so concentrated: although Eriugena pertinently stipulated Gottschalk's skewed interpretation of Augustine's position, he also presented his own and unique account of the relation between sin and human nature and his resistance against the notion of eternal damnation. For Eriugena, his association between the eternal, uncreated goodness of God and created human nature, and his intimate relation of all created beings to God's eternal understanding (as later thoroughly explicated in the Periphyseon), was just too compelling and potent as to disqualify the permanent annihilation of human identity in eternal inferno. Catherine Kavanagh's (2020:326-345) 'Eriugena the Exegete:
Hermeneutics in a Biblical context' presents an introduction to the theoretical aspects of Eriugena's Biblical hermeneutics (although, as previously mentioned, a rigid distinction between 'theoretical' and 'practical' exegesis in Eriugena's frame cannot be sustained): for him, exegesis involves, as Guiu (2020b:297) earlier in the volume showed, an attempt to 'read' the 'two books' written 'by God': the 'book of scripture' and the 'book of nature' (or creation), pointing towards a hermeneutic that includes logic, physics, theology and philosophy. Kavanagh (2020) departs from what she clearly considers as a somewhat prejudiced understanding of Eriugena as the 'great isolated dialectician' and only systematic philosopher from the Carolingian period in the West, yet in that 'systematic' regard heavily indebted to Pseudo-Dionysius, whilst the:

[C]ulture of Biblical exegesis that surrounded hom is often perceived to have been derivative, largely unphilosophical, lacking in any real theological interest, concerned only with questions of a devotional or perhaps legal nature. (p. 326)

Kavanagh counters this common reception of Eriugena by thoroughly investigating both the Occident (in the contemporary Western approaches of the 9th century, Western patristics and the arts curriculum) and Byzantine (particularly the dialectical method of Dionysius and the cosmology of Maximus) sources of Eriugena's exegesis. After a survey of what she considers to be the most relevant literature relating to Eriugenian exegesis as a 'relatively recent development' (Kavanagh 2020:326; including inter alia De Lubac, McGinn, Otten and Marler) and thoroughly acknowledging the impact of SPES' conferences in providing impetus to the formation of this literature (especially Conference IX of June 1995, which dealt with hermeneutics specifically; Kavanagh 2020:327[fn.2]), Kavanagh (2020:328ff.) provides an own analysis of the function and character of exegesis in Eriugena's oeuvre in general.

The fourth and last section of the volume (cf. Guiu 2020c:5-6) explores Eriugena's impact on developments in the later Western history of ideas, from the early scholastic period of the 12th century well into early modernity. It was especially in 12th-century France that Eriugena's philosophical theology had an effect, before the final condemnation of the Periphyseon in 1225. Agniezka Kijewska (2020:349-386; 'Eriugena's Influence on the 12th century') traces Eriugena's influence to his veiled disseminator Honorius Augustodunensis, Hugo of St Victor and Richard of St Victor, Suger of Saint-Denis, Thierry and the School of Chartres, and John of Salisbury, to mention a few. Not only the Periphyseon but also Eriugena's translation of and commentary on the Corpus Dionysiacum and the sermon and commentary on the Gospel of John are singled out as important sources for the development of scholastic thought in the 12th century. Kijewska notes that Eriugena's influence was subtle and not explicit: however, some echoes in early scholastic thought are unmistakeably Eriugenian. This is also stressed in David Albertson's reading (2020:387-418; 'Echoes of Eriugena in Renaissance Philosophy: Negation, Theophany, Anthropology'), in which Eriugena's influence 
is traced in the 14th-century Meister Eckhart (ca.1260-1328) and the 15th-century Nicholas of Cusa (1401-1464), the last Medieval philosopher or Gilsonian 'gatekeeper of modernity' on the doorstep of the Renaissance. The Dominican Eckhart, himself posthumously condemned in 1329, and particularly Cusa's engagements with and indeed his indebtedness to Eriugena are indicated as fundamental in the development of their mystical theologies. The respected Eriugena specialist Dermot Moran's (2020:419-446; also see Moran 1989, 1990, 2008) 'The Reception of Eriugena in Modernity: A Critical Appraisal of Eriugena's Dialectical Philosophy of Infinite Nature' traces the reception of Eriugena well into modernity, with specific reference to Thomas Gale (1636-1702) who made the first printing of the Periphyseon in 1681 and the exposition of Eriugenian ideas in post-Hegelian contexts. After providing an overview of the complex evolution of the manuscripts of the Periphyseon 'from the time that it emerged in Eriugena's scriptorium workshop' (Moran 2020:420) into the Middle Ages, Renaissance and modernity, Moran discusses two Eriugenian ideas that are shown to have had productive outcomes in its post-Hegelian application, inter alia in phenomenology, ${ }^{18}$ namely, his presumed idealism and the dialectical element in his thinking, both appreciated in Hegelian and postHegelian studies because of their flexibility and inclusive rationality. The eminent historian of ideas, Stephen Lahey (2020:447-453; 'Eriugena's Condemnation and his Idealism'), concludes the editorial work by isolating the probable reason why the Periphyseon was finally condemned in 1225 , namely, that this primary text and its author were linked to the rather notorious teachings of Amalric of Bène (d.1204/7) in 1210 (perhaps best encapsulated ${ }^{19}$ in omnia sunt Deus ['God is all']; omnia unum, quia quidquid est, est Deus ['all things are one, because whatever is, is God'], leading to the preliminary condemnation of the Periphyseon in the same year. Amalric and his associates were clearly pantheistic and Eriugena's disappearance from the still early phase of scholasticism precisely during this decade has long been taken to result from some association between him and Amalric. The final banning of the reading of the Periphyseon and Eriugena's other works saves the translation of and commentary on the Corpus Dionysiacum (which was what Eckhart and Cusa had access to) followed in 1225. As editor Guiu (2020c:6) finally notes, the 'aura of pantheism has remained with Eriugena into the present'.

\section{Concluding remarks}

This article chartered the development of SPES over the past five decades and connected it to the publication

18.Donald F. Duclow's (1977) article on "Divine Nothingness and Self-Creation" in Eriugena vis-a-vis Heidegger's conviction that when raising the question of nothingness 'we stand in a tradition' which 'must be taken into account' (Duclow 1977:109[fn.2]) could well be read in close proximity to Moran's analysis of the phenomenological application of Eriugena's thought. Also, see Duclow's (2006) critical juxtapositioning of Eriugena, Eckhart and Cusa.

19.For the list consisting of the 14 'errors' of Amalric's followers compiled in Garner of Rupefort's Contra Amaurianos in 1210, the year of Amalric's trial, see Lahey (2020:447-448) (2020:447-448). Lahey (2020:448) stresses that although 'T t has become widely [..] the disappearance sisappearance is connected to Amalic's condemnation [...] the disappearance may be better explained by the concurrent antipath towards philosophical thought at Paris with the appearance of Aristotelian ideas' in the early 13 th century. of A Companion to John Scottus Eriugena in 2020, as concisely discussed supra. The article attempted to contribute to SPES' 50-year jubileum by summarising its conference outputs over the past five decades as well as associating the society's work to this particular publication, thereby furthering its laborious efforts and specialist research outputs to a broader, non-specialised readership.

It should be clear that the Society for the Promotion of Eriugena Studies has indeed done justice to its name and honoured its initial objectives: from July 1970 it has methodically linked Eriugena scholars globally and promoted Eriugenian studies on a massive scale, with few societal equivalents in recent Medieval scholarship. The proceedings of the conferences under the auspices of SPES and the publication of Guiu's editorial work in 2020 have significantly contributed to a still relatively young but already established erudition regarding Eriugena's contributions as an Irish philosopher, Christian theologian, formidable translator and unique exegete from the Carolingian period in the early Middle Ages.

\section{Acknowledgements}

The author is an associate of the Center for the History of Philosophy and Science (CHPS), Radboud University Nijmegen, the Netherlands.

\section{Competing interests}

The author declares that he has no financial or personal relationships which may have inappropriately influenced him in writing this article.

\section{Author's contributions}

I declare that I am the sole author of this research article.

\section{Ethical considerations}

This article followed all ethical standards for a research without direct contact with human or animal subjects.

\section{Funding information}

This research received no specific grant from any funding agency in the public, commercial or not-for-profit sectors.

\section{Data availability}

Data sharing is not applicable to this article as no new data were created or analysed in this study.

\section{Disclaimer}

The author declares that opinions presented in this article are the author's own and do not reflect the opinions of any institution or organisation. 


\section{References}

Albertson, D., 2020, 'Echoes of Eriugena in renaissance philosophy: Negation theophany, anthropology', in A. Guiu (ed.), A companion to John Scottus Eriugena, pp. 387-418, Brill, Leiden.

Allard, G.-H. (ed.), 1986, Jean Scot Écrivain, Actes du IV Colloque international, Montreal, 28 aout -2 septembre 1983, Vrin, Paris.

Barstad, J.I., 2020, 'Eriugena as translator and interpreter of the Greek fathers', in A. Guiu (ed.), A companion to John Scottus Eriugena, pp. 267-295, Brill, Leiden.

Beierwaltes, W. (ed.), 1980, Eriugena. Studien zu seinen Quellen, Abhandlungen der Heidelberger Akademie der Wissenschaften. Philosophisch-historische Klasse, Vorträge des III. Internationalen Eriugena-Colloquiums, Freiburg im Breisgau, 2730 August 1979, Carl Winter, Heidelberg.

Beierwaltes, W. (ed.), 1987, Eriugena Redivivus: Zur Wirkungsgeschichte Seines Denkens Im Mittelalter Und Im Übergang Zur Neuzeit, Abhandlungen Der Heidelberger Akademie Der Wissenschaften, Philosophisch-Historische Klasse, Vorträge des V. Internationalen Eriugena-Colloquiums, Werner-Reimers-Stiftung, Bad Homburg, 26-30 August 1985, Carl Winter, Heidelberg.

Beierwaltes, W. (ed.), 1990, Begriff und Metapher: Sprachform des Denkens be Eriugena, Abhandlungen Der Heidelberger Akademie Der Wissenschaften, Philosophisch-Historische Klasse, Vorträge des VII. Internationalen EriugenaColloquiums, Werner-Reimers-Stiftung, Bad Homburg, 26-29 Juli 1989, Carl Winter, Heidelberg.

Bett, H., 1925, Johannes Scottus Erigena: A study in medieval philosophy, Cambridge University Press, Cambridge.

Beukes, J., 2020, Middeleeuse Filosofie, vols 1 \& II, Akademia, Pretoria.

Cappuyns, M., 1933, Jean Scot Érigène. Sa vie, son oeuvre, sa pensée, Abbaye du Mont César, Louvain.

Carabine, D., 2000, John Scottus Eriugena, Oxford University Press, Oxford.

Contreni, J.J., 2020, 'John Scottus, Nutritor, and the liberal arts', in A. Guiu (ed.), A companion to John Scottus Eriugena, pp. 31-63, Brill, Leiden.

Copleston, F.C., 1993, A history of philosophy volume II, medieval philosophy Doubleday, New York, NY.

Corrazon, R., 2019, 'The works of Eriugena: Editions and translations', pp. 1-25, viewed 12 March 2021, from https://www.ontology.co/biblio/eriugena-editions. htm

Costambeys, M., Innes, M. \& MacLean, S., 2014, The Carolingian world, Cambridge Medieval Textbooks, Cambridge.

D'Onofrio, G., 1994, 'The concordance of Augustine and Dionysius: Toward a hermeneutic of disagreement of patristic sources in John the Scot's Periphyseon' in B. McGinn \& W. Otten (eds.), Eriugena: East and west, Papers of the VIII International Colloquium of the Society for the Promotion of Eriugenian Studies, Chicago and Notre Dame, 18-20 October 1991, pp. 115-140, University of Notre Chicago and Notre Dame, 18
Dame Press, Notre Dame, IN.

D'Onofrio, G., 2020, 'The speculative system of John Scottus Eriugena and the tradition of Vera Philosophia', in A. Guiu (ed.), A companion to John Scottus Eriugena, pp. 213-238, Brill, Leiden.

Denifle, H. (O.P.) (ed.), 1889, Chartularium Universitatis Parisiensis, vol. I, \#128, Delalain, Paris.

Duclow, D.F., 1977, 'Divine nothingness and self-creation in John Scotus Eriugena', The Journal of Religion 57(2), 109-123. https://doi.org/10.1086/486526

Duclow, D.F., 2006, Masters of learned ignorance: Eriugena, Eckhart, Cusanus, Variorum Collected Studies 851, Routledge, London.

Erismann, C., 2020, 'Between Greek and Latin: Eriugena on logic', in A. Guiu (ed.), A companion to John Scottus Eriugena, pp. 93-110, Brill, Leiden.

Eriugena, J.S., 1996-2003, Periphyseon, vols I - V, E.A. Jeauneau (ed.), Corpus Christianorum Continuatio Mediaevalis, pp. 161-165, Brepols, Turnhout. Translations
in I.P. Sheldon-Williams (ed. \& transl. 1968, 1972, 1982) and J.J. O'Meara \& I.P. Sheldon-Williams (in Jeaneau [ed.] 1995 \& 2003). Additional translations: Periphyseon (The Division of Nature), transl. I.P. Sheldon-Williams, revised by J.J. O'Meara, 1987 (The Division of Nature), transl. I.P. Sheldon-Williams, revised by J.J. O'Meara, 1987
(out of print), Montréal, Bellarmin \& Washington, Dumbarton Oaks; John the Scot, (out of print), Montréal, Bellarmin \& Washington, Dumbarton Oaks; John the Scot,
Periphyseon on the Division of Nature, transl. M.L. Uhlfelder, J.A. Potter (intr.), 1976 reprint 2011, Eugene OR, Wipf and Stock, viewed 16 June 2021, from https:// wipfandstock.com/9781610976305/periphyseon-on-the-division-of-nature/.

Gavin, J., 2020, ‘A theologian's itinerary: John Scottus Eriugena's Christological ascent', in A. Guiu (ed.), A companion to John Scottus Eriugena, pp. 134-153, Brill, Leiden.

Grabmann, M., 1957, Die Geschichte der scholastischen Methode, vols I \& II, Akademie Verlag, Berlin.

Guiu, A., 2020a, 'Appendix: Benedict XVI assesses Eriugena', in A. Guiu (ed.), A companion to John Scottus Eriugena, pp. 454-457, Brill, Leiden.

Guiu, A., 2020b, 'Eriugena reads Maximus confessor: Christology as cosmic theophany', in A. Guiu (ed.), A companion to John Scottus Eriugena, pp. 296-325, Brill, Leiden.

Guiu, A., 2020c, 'Introduction', in A. Guiu (ed.), A companion to John Scottus Eriugena pp. 1-6, Brill, Leiden

Hankey, W., 1998, 'Augustinian immediacy and Dionysian mediation in John Colet, Edmund Spenser, Richard Hooker, and the Cardinal de Bérulle', in D. De Courcelles (ed.), Augustinus in der Neuzeit, Colloque de la Herzog August Bibliothek de Wolfenbüttel, 14-17 octobre 1996, pp. 125-160, Editions Brepols, Turnhout.

Haren, M., 1985, Medieval thought. The western intellectual tradition from antiquity to the thirteenth century, Macmillan, London.
Harrington, L.M., 2004, A thirteenth-century textbook of mystical theology at the University of Paris. The mystical theology of Dionysius the Areopagite in Eriugena's Latin translation with the Scholia translated by Anastasius Eriugena's Latin translation with the Scholia translated by A
the Librarian and excerpts from Eriugena's Periphyseon, Peeters, Paris.

Harrington, L.M., 2020, 'Eriugena and the Neoplatonic tradition', in A. Guiu (ed.), A companion to John Scottus Eriugena, pp. 64-92, Brill, Leiden.

Honorius Augustodunensis, 1974, Clavis Physicae, P. Lucentini (ed.), Temi e Testi 21, Edizioni di Storia e Letteratura, Rome.

Hyman, A., Walsh, J.J. \& Williams, T. (eds.), 2010, Philosophy in the middle ages: The Christian, Islamic and Jewish traditions, Hackett, Indianapolis.

Jeauneau, E.A., (ed.), 1995, Iohannis Scotti Eriugenae, Periphyseon (De Divisione Naturae), Liber Quartus, transl. J.J. O'Meara \& I.P. Sheldon-Williams, M.A. Zier (co-ed.), School of Celtic Studies \& Dublin Institute for Advanced Studies, Dublin.

Jeauneau, E.A. (ed.), 2003, Iohannis Scotti Eriugenae, Periphyseon (De Divisione Naturae), Liber Quintus, transl. J.J. O'Meara \& I.P. Sheldon-Williams, M.A. Zier (co-ed.), School of Celtic Studies \& Dublin Institute for Advanced Studies, Dublin.

Kavanagh, C., 2020, 'Eriugena the Exegete: Hermeneutics in a Biblical context', in A. Guiu (ed.), A companion to John Scottus Eriugena, pp. 326-345, Brill, Leiden.

Kijewska, A., 2020, 'Eriugena's influence on the 12th century', in A. Guiu (ed.) A companion to John Scottus Eriugena, pp. 349-386, Brill, Leiden.

Lahey, S., 2020, 'Eriugena's condemnation and his idealism', in A. Guiu (ed.), A companion to John Scottus Eriugena, pp. 447-453, Brill, Leiden.

Leonardi, C. (ed.), 1989, Giovanni Scoto Nel Suo Tempo: L'organizzazione Del Sapere in Età Carolingia, Atti del VI. Convegno storico internazionale, Todi, 11-14 ottobre 1987, Centro italiano di studi sull'Alto Medioevo, Spoleto.

Lloyd-Sidle, E.M., 2020, 'A thematic introduction to and outline of the Periphyseon for the Alumnus', in A. Guiu (ed.), A companion to John Scottus Eriugena, pp. 113-133, Brill, Leiden.

Luibheid, C. (transl.), 1987, Pseudo-Dionysius: The complete works, P. Rorem (intr.), Paulist Press, New York, NY.

Mainoldi, E.S., 2020, 'Eriugena's intervention in the debate on predestination', in A Guiu (ed.), A companion to John Scottus Eriugena, pp. 241-266, Brill, Leiden.

Marenbon, J., 1981, From the circle of Alcuin to the School of Auxerre, Cambridge University Press, Cambridge.

Marenbon, J., 1988. Early medieval philosophy (488-1150). An introduction, Routledge, New York, NY.

McEvoy, J., 1987, 'loannes Scottus Eriugena and Robert Grosseteste', in W. Beierwaltes (ed.), Eriugena Redivivus: Zur Wirkungsgeschichte Seines Denkens Im Mittelalter Und Im Übergang Zur Neuzeit, Abhandlungen Der Heidelberger Akademie Der Wissenschaften, Philosophisch-Historische Klasse, Vorträge des V. Internationalen Eriugena-Colloquiums, Werner-Reimers-Stiftung, Bad V. Internationalen Eriugena-Colloquiums, Werner-Reimers-Stiftung,
Homburg, 26-30 August 1985, pp. 192-213, Carl Winter, Heidelberg.

McEvoy, J. \& Dunne, M. (eds.), 2002, History and eschatology in John Scottus Eriugena and his time, Proceedings of the $\mathrm{X}$ International Conference of the Society for the Promotion of Eriugenian Studies held at Maynooth and Dublin, 16-20 August 2000, Leuven University Press, Louvain.

McGinn, B., 2020, 'The Periphyseon as Hexaemeral commentary', in A. Guiu (ed.), A companion to John Scottus Eriugena, pp. 154-188, Brill, Leiden.

McGinn, B. \& Otten, W. (eds.), 1994, Eriugena: East and west, Papers of the VIII International Colloquium of the Society for the Promotion of Eriugenian Studies, Chicago and Notre Dame, 18-20 October 1991, University of Notre Dame Press, Notre Dame, IN.

McKitterick, R., 2004, History and memory in the Carolingian world, Cambridge University Press, Cambridge.

Moran, D., 1989, The Philosophy of John Scottus Eriugena. A study of idealism in the middle ages, Cambridge University Press, Cambridge.

Moran, D., 1990, 'Pantheism from John Scottus Eriugena to Nicholas of Cusa', American Catholic Philosophical Quarterly LXIV(1), 131-151. https://doi. org/10.5840/acpq199064146

Moran, D., 2008, 'John Scottus Eriugena', in E.N. Zalta (ed.), The Stanford encyclopedia of philosophy (Fall 2008 edition), viewed 15 April 2021, from https://plato.stanford.edu/entries/scottus-eriugena/.

Moran, D., 2014, 'Christian Neoplatonism and the phenomenological tradition: The hidden influence of John Scottus Eriugena', in W. Otten \& M.I. Allen (eds.) Eriugena and creation, Instrumenta Patristica et Mediaevalia 68, Proceedings of the XI International Conference on Eriugenian Studies held in honor of Édouard Jeauneau, pp. 601-636, Brepols, Turnhout.

Moran, D., 2020, 'The reception of Eriugena in modernity: A critical appraisal of Eriugena's dialectical philosophy of infinite nature', in A. Guiu (ed.), A companion to John Scottus Eriugena, pp. 419-446, Brill, Leiden.

Oldcurrencyexchange, n.d., O'Brien Banknote Guide: Five Pounds, Irish Banknote 'B Series' viewed n.d., from https://oldcurrencyexchange.com/2015/07/13/obrienbanknote.

O’Meara, J.J., 1988, Eriugena, Clarendon Press, Oxford.

O'Meara, J.J. \& Bieler, L. (eds.), 1973, The mind of Eriugena, Papers of a Colloquium on Eriugena, Dublin, 14-18 July 1970, Irish University Press, Dublin.

Otten, W., 1991, The anthropology of Johannes Scottus Eriugena, Brill, Leiden.

Otten, W., 2013, 'Eriugena, John Scottus', in K. Pollmann \& W. Otten (eds.), The Oxford guide to the historical reception of Augustine, pp. 938-941, Oxford University Press, Oxford. 
Otten, W., 2020a, 'Suspended between cosmology and anthropology: Natura's bond in Eriugena's Periphyseon', in A. Guiu (ed.), A companion to John Scottus Eriugena, pp. 189-212, Brill, Leiden.

Otten, W., 2020b, Thinking nature and the nature of thinking: From Eriugena to Emerson, Stanford University Press, Redwood City, CA.

Otten, W. \& Allen, M.I. (eds.), 2014, Eriugena and creation, Instrumenta Patristica et Mediaevalia 68, Proceedings of the XI International Conference on Eriugenian Studies, held in honor of Édouard Jeauneau, Chicago, 9-12 November 2011 Brepols, Turnhout.

Pseudo-Dionysius, 1990-1991, Corpus Dionysiacum, vols I \& II, B. Suchla, G. Heil \& A.M. Ritter (eds.), Patristische Texte und Studen, vols 33 \& 36, Walter de Gruyter, Berlin.

Roques, R. (ed.), 1977, Jean Scot Erigène et l'histoire de la philosophie, Actes du II Colloque International, Laon, 7-12 juillet 1975, Éditions du Centre national de la recherche scientifique, Paris.

Rorem, P., 1993, Pseudo-Dionysius: A commentary on the texts and an introduction to their influence, Oxford University Press, Oxford.

Sheldon-Williams, I.P., 1967, 'Johannes Scottus Eriugena', in A.H. Armstrong (ed.), The Cambridge history of later Greek and early medieval philosophy, pp. 518-531, Cambridge University Press, Cambridge.
Sheldon-Williams, I.P. (ed. \& transl.), 1968, Iohannis Scotti Eriugenae, Periphyseon (De Divisione Naturae), Liber Primus, L. Bieler (co-ed.), Dublin Institute for Advanced Studies, Dublin.

Sheldon-Williams, I.P. (ed. \& transl.), 1972, Iohannis Scotti Eriugenae, Periphyseon (De Divisione Naturae), Liber Secundus, L. Bieler (co-ed.), Dublin Institute for Advanced Studies, Dublin.

Sheldon-Williams, I.P. (ed. \& transl.), 1982, Iohannis Scotti Eriugenae, Periphyseon De Divisione Naturae), Liber Tertius, L. Bieler (co-ed.), Dublin Institute for Advanced Studies, Dublin.

Sheldon-Williams, I.P. (transI.), 1995, Iohannis Scotti Eriugenae, Periphyseon (De Divisione Naturae), Liber Quartus, J.J. O'Meara (co-transl.), E.A. Jeauneau (ed.), M.A. Zier (co-ed.), Dublin Institute for Advanced Studies, Dublin.

Siewers, A.K., 2020, 'Eriugena's Irish background', in A. Guiu (ed.), A companion to John Scottus Eriugena, pp. 9-30, Brill, Leiden.

Tugwell, S. (O.P.), (transl., ed. \& intr.), 1988, Albert and Thomas: Selected writings, Paulist Press, New York, NY.

Van Riel, G., Steel, C. \& McEvoy, J. (eds.), 1996, lohannes Scottus Eriugena: The Bible and hermeneutics, Proceedings of the IX International Colloquium of the Society for the Promotion of Eriugenian Studies held at Leuven and Louvain-la-Neuve, 7-10 June 1995, Leuven University Press, Louvain.

Weiner, S.F., 2007, Eriugenas Negative Ontologie, B.R. Grüner, Amsterdam. 